\author{
녹비작물의 경작형태와 우분액비시용이 벼와 사료작물의 생산성 \\ 및 양분이동에 미치는 영향 \\ 육완방 ${ }^{1}$ 최기춘 ${ }^{2} \cdot$ 이경보 $^{3} \cdot$ 강요셉 ${ }^{4} \cdot$ 윤 $^{^{\prime}}{ }^{4}$
}

\title{
Effects of Forage Cropping System and Cattle Slurry Application on Productivity of Rice and Forage Crops and Nutrient Movement in Paddy Land
}

Wan Bang Yook ${ }^{1}$, Ki Choon Choi ${ }^{2}$, Kyeong Bo Lee ${ }^{3}$, Yo Sep Kang ${ }^{4}$ and Chang Yoon ${ }^{4}$

\begin{abstract}
This study was conducted to investigate the effects of green manure crops and cattle slurry application on rice productivity and nutrient movement in paddy land. Cropping systems used in this study were consisted of five designs, such as mono-cropping rice applied with standard fertilizer (MRS), doublecropping whole crop barley following rice applied with cattle slurry (DWBRC), double-cropping whole crop rye following rice applied with cattle slurry (DWRRC), mono-cropping rice applied with following milk vetch (MRMV) and mono-cropping rice applied with following hairy vetch (MRHV). The field experiments were conducted on the clay loam at Backsanmyun, Kimje, Chunlabukdo province in Korea for three years (May 2006 to Apr. 2009). This study was arranged in completely randomized design with three replicates. Culm and panicle length of rice were higher in MRS than other treatments. Ripened grain ratio was higher in MRS than other treatments. Yield of Grain showed high in MRS, DWBRC and DWRRC than MRMV and MRHV. The yield of dry matter(DM) of whole crop barley in DWBRC increased significantly as compared with that of rye in DWRRC. The $\mathrm{pH}$, and contents of $\mathrm{T}-\mathrm{N}, \mathrm{P}_{2} \mathrm{O}_{5}$ and organic matter $(\mathrm{OM})$ and exchangeable cation $(\mathrm{Ca}, \mathrm{Na}, \mathrm{Mg}$ and $\mathrm{K})$ in soil samples collected at the end of the experiment were remarkably higher than those at the beginning of the experiment. The concentrations of $\mathrm{NO}_{3}-\mathrm{N}_{2} \mathrm{NH}_{4}-\mathrm{N}$ and $\mathrm{PO}_{4}$ in discharge water in DWBRC and DWRRC were higher than MRS.
\end{abstract}

(Key words : Rice, Forage crops, Cattle slurry, Soil property, Discharge water)

I . 서 론 과다 시용과 유출에 의한 수질오염과 적절하게 농업활동에 의한 환경오염원은 화학비료의 겅리되지 못하고 방류되는 츼핵산분뇨, 토으리야과
함께 유실되는 영양성분

${ }^{1}$ 건국대학교 동물생명과학대학(College of Animal Bioscience and Technology, Konkuk University, Seoul 143-701, Korea)

${ }^{2}$ 농촌진흥청 국립축산과학원 (National Institute of Animal Science, RDA, Seonghwan-Eup, Cheonan-Si, Chungnam, 330-801)

3 국립식량과학원 (National Institute of Crop Science, RDA, Iksan-Si, Chonbuk, 570-080)

4 전북대학교 동물생명공학과 (Dept. of Animal Resources and Biotechnology, Chonbuk National University, Jeonju 561-756, Korea)

Corresponding author: Dr. Chang Yoon, Dept. of Animal Resources and Biotechnology, Chonbuk National University, Jeonju 561-756, Korea Phone:82-63-270-2549, Fax:82-63-270-2612, E-mail:cyoon@jbnu.ac.kr 
등이 있다. 특히 가축분뇨는 자연에 방치할 경 우 수질오염, 악취발생, 위생악화 등 심각한 환 경문제를 일으킬 수 있기 때문에 가축분뇨에 대한 환경규제는 점차 강화되고 있는 추세이 다. 이는 가축분뇨 중의 질소, 인산, 세균 및 유기물함량이 높아 지표수 및 지하수를 오염시 키고 인축의 피해와 하천의 부영양화를 초래하 기 때문에 축산에 있어서 중요한 문제로 인식 되고 있다. 가축의 분뇨는 그 종류에 따라 유 기와 무기 $\mathrm{N}$ 의 비율은 가축이나 사료의 종류에 따라 차이가 있고 $(50 \sim 80 \%$ 의 무기 $\mathrm{N}), \mathrm{P}$ 와 $\mathrm{K}$ 는 $80 \sim 90 \%$ 가 무기태로 되어 있어 그 이용효율이 현저히 높다.

가축분뇨가 비료원으로 토양에 환원될 때 주 로 문제가 되는 것이 질소와 인으로, 질소를 과잉 시용하면 가축이 섭취한 사료를 통하여 질산중독을 일으킬 수 있으며 (Goh와 Vityakon, 1986), 흡수되지 못하는 질소는 용탈 (Davies 등, 1996), 유실 (Gilley 등, 1999)되고, 강우에 의해 유실되거나 용탈되는 양은 많기 때문에 지하수에 유입되어 지하수 오염의 원인이 된다 (육, 1990; Jarvis 등, 1987; PYe, 1983; Legg와 Meisinger, 1982; McCalla, 1974).

가축 사육에 의한 분뇨 배설량은 2009년 기 준으로 년간 약 4천1백만 톤이 되며 여기에 함 유되어 있는 비료성분은 질소가 약 23만 톤, 인산이 약 7 만 톤, 그리고 칼리가 약 9 만 톤이 된다. 비료성분이 풍부한 가축분뇨는 자원으로 서 재활용하여야 하는데 축분의 경우에는 재활 용에 많은 진전을 보이고 있으나 분뇨혼합, 즉 슬러리의 경우에는 그렇지 못한 형편이다. 그 러므로 혼합분뇨를 액비로 이용하는 기술을 개 발하여 가급적이면 슬러리 형태의 액비로 농경 지에 이용하도록 하는 것이 경제적이다.

가축 분뇨의 이용을 확대하기 위해서는 인근 경종농가, 특히 벼 재배에 이용하는 방안을 강 구할 수 있다. 우리나라 농경지의 약 $62 \%$ 를 차 지하는 논에 재배되고 있는 벼의 비료원으로 슬러리를 이용할 수 있다면, 이는 살포경지면
적을 확대하는 의미가 되는 동시에 자원을 더 욱 효율적으로 활용하게 된다. 또한 우리나라 의 조사료 공급비율은 $30 \%$ 이하일 뿐 만 아니 라 조사료의 해외 의존도가 $17 \%$ 에 달하고 있 어 양축농가에서는 분뇨처리의 어려움과 함께 조사료 생산을 위한 경지가 부족하므로 부족한 조사료 생산을 충족시키기 위해서는 논에 유기 질 비료자원인 가축분뇨를 지속적으로 도입, 비료자원화 함과 동시에 조사료 자원의 증산에 도 기여할 수 있으리라고 본다. 가축분뇨 발효 액비를 자원화하여 농경지에 적정량을 시용하 면, 토양의 $\mathrm{pH}$, 탄소, 질소, 양이온치환용량이 증가된다(Yadav 등, 2000; Choudhary 등, 1996). 그러나 가축분뇨를 과다하게 시용하면 조공극량이 감소되고 투수성 저하와 견지성이 악화되어 토양의 물리성이 나빠지고(Ushio 등, 2000), 토양 산화환원전위가 낮아져 유해물질이 생성되고 벼 재배시 질소흡수량이 증가되어 도 복발생의 원인이 되는 한편, 잉여양분은 물의 이동을 따라 수계오염의 원인 (농림부, 2000 , 임 등, 2006, 2007)이 되기 때문에 무엇보다 적절 한 시용이 중요하다 (Murayama 등, 2001).

따라서 본 연구는 우분액비에 의한 답리작 사료작물 재배 및 녹비작물 재배 후 벼 및 답 리작물의 생산성, 토양의 지력증진 효과 및 양 분이동에 미치는 영향을 조사하기 위하여 실시 하였다.

\section{․ 재료 및 방법}

본 시험은 농가실증실험으로 시험전까지 벼 재배만을 해온 전라북도 김제군에 소재한 식양 토의 논을 이용하여 2006년 4월부터 2009년 4 월까지 3 년 동안 수행하였으며 공시토양의 성 분은 Table 1 과 같다.

시험용 우분액비는 김제시 백산면 시험포 부 근에 위치한 착유우 목장의 슬러리 저장조에서 수집한 혼합슬러리를 시험포장에 설치한 액비 저장통 $(1,000 \ell)$ 에 옮겨 6 개월 이상 부숙시켜 
Table 1. Characteristics of soil collected at beginning of experiment in paddy land

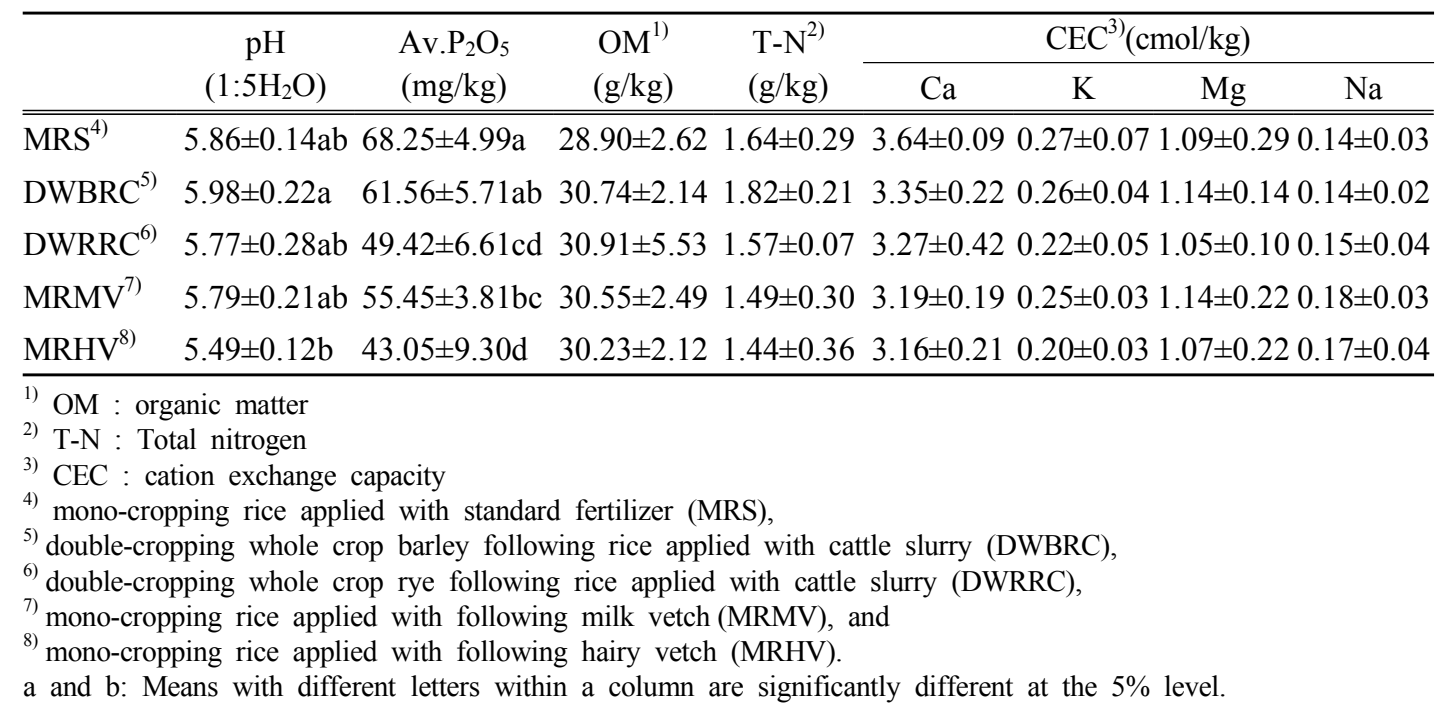

이용하였는데, 우분액비의 성분은 Table 2에 나 타난 바와 같이 질소 $0.52 \sim 0.55 \%$, 인산 $0.24 \sim$ $0.44 \%$, 수분 함량이 $90 \sim 92 \%$ 로 매우 균일하게 조제되어 있었다. 우분액비의 시용은 매 시용 시기 마다 시료를 채취하여 성분을 분석한 다 음 $\mathrm{N}$ 성분을 기준으로 시용수준을 결정하였으 며 벼는 이앙 전에 전량 기비로, 답리작인 총 체보리 및 호밀은 파종 전과 봄 생육 개시 전 에 2회 균등분할 시용하였다. 벼는 $\mathrm{N}$ 기준으로 $110 \mathrm{~kg}$, 호밀과 총체보리는 $150 \mathrm{~kg} / \mathrm{ha}$ 을 살포하 여 화학비료를 사용하지 않고 우분액비만 시용 하였을 때의 생육 및 양분이동에 미치는 영향 을 조사하였다.

본 시험은 벼 화학비료 단작 표준구 (MRS), 벼 + 총체보리 2모작 우분액비 시용구 (DWBRC), 벼 + 호밀 2모작 우분액비 시용구 (DWRRC), 벼 + 자운영 (MRMV) 및 벼 + 베치 (MRHV)로 구성 하였다. 화학비료 대비 우분액비 시용수준은 $\mathrm{N}$ 을 기준으로 하였으며 벼 화학비료 단작 표준 구 $\left(\mathrm{N}: 110, \mathrm{P}_{2} \mathrm{O}_{5}: 45, \mathrm{~K}_{2} \mathrm{O}: 57 \mathrm{~kg} / \mathrm{ha}\right)$ 는 표준시비법
으로 시용하였으며 시험구당 $333 \mathrm{~m}^{2}$ 로 완전임 의 3 반복으로 배치하였다.

벼의 공시품종은 ‘남평벼'로 3 년 동안 매년 6 월 초에 재식거리 $30 \times 15 \mathrm{~cm}$ 로 기계 이앙하였 다. 총체보리 '영양보리'와 호밀 'Koolgrazer'은 11월 초순, 녹비작물인 자운영 (Astragalus sinicus L.)과 헤어리베치 'Oregen common'는 벼 수확 시 입모중에 파종하였으며 시비, 제초, 병충해 방제 등의 포장관리는 처리구에 관계없이 동일 하게 농가의 관행적인 방법으로 수행하였다.

벼의 간장, 수장, 수수, 등숙비율 등 수량구 성요소와 수량은 채취 된 시료를 이용하여 농 사시험연구조사기준 $(\mathrm{RDA}, 1995)$ 에 준하여 조 사하였다. 사료작물의 생산성은 관행에 의하여 적기에 수확하였는데 시험구별로 임의로 3지점 에서 $1 \mathrm{~m}^{2}$ 씩 수확하여 생초무게를 측정한 후 그 중 일부 $(500 \mathrm{~g}$ 내외)를 채취하여 칭량한 후 $70^{\circ} \mathrm{C}$ 건조기에서 48 시간 이상 건조하여 건물율 을 구하고 그에 따라 단위면적당 생산량을 산 출하였다. 채취된 시료는 건조한 후 $20 \mathrm{mesh}$ 의

Table 2. Major properties of cattle slurry used in this experiment (\%)

\begin{tabular}{ccccccc}
\hline Moisture & $\mathrm{N}$ & $\mathrm{P}_{2} \mathrm{O}_{5}$ & $\mathrm{~K}_{2} \mathrm{O}$ & $\mathrm{CaO}$ & $\mathrm{MgO}$ & $\mathrm{Na}_{2} \mathrm{O}$ \\
\hline \hline $90.1 \sim 92.1$ & $0.52 \sim 0.55$ & $0.24 \sim 0.44$ & $0.39 \sim 0.44$ & $0.24 \sim 0.42$ & $0.13 \sim 0.20$ & $0.13 \sim 0.21$ \\
\hline
\end{tabular}


Wiley mill로 분쇄하여 실험실내 desiccator에 보관하였다가 조단백질 함량은 Kjeldahl 정량법 (AOAC, 1993)으로, NDF 및 $\mathrm{ADF}$ 함량은 Van Soest법 (1970)에 의해 분석하였으며 TDN은 Jurgen(1982)이 제시한 방법에 따라 계산하였 다. 토양성분의 조사는 시험전후 작토층 토양 시료를 채취하여 실내에서 자연 건조한 다음 이를 잘 마쇄 하여 토양분석법 (농촌진흥청, 1989)에 준하여 분석하였는데, 채취된 토양은 건조후 $2 \mathrm{~mm}$ 체로 조제후 분석시료로 사용하 였다. 시료의 처리와 분석에서 발생될 수 있는 제반오류와 분석의 정밀도 및 정확도를 검정하 기 위하여 모든 시료 분석에는 공시료 (Reagent blank)와 반복시료를 사용하였다. 논으로부터 배출수 성분 조사는 시험구별로 배출구에 배출 수 수집통을 설치하고 벼 재배기간 동안 강우 후와 논물을 뺄 때 배출수통에 수집된 배출수 를 채취하여 $\mathrm{NO}_{3}-\mathrm{N}, \mathrm{NH}_{4}-\mathrm{N}$ 및 $\mathrm{PO}_{4}$ 의 농도 (FIAStar 5000 Analyzer, Foss Tecator, Sweden) 를 측정하였다.

통계분석은 Windows 용 SPSS/PC (Statiscal Package for the Social Science, ver 12.0. USA) 통계 프로그램을 이용하여 분석하였다.

\section{III. 결과 및 고찰}

\section{1. 벼의 수량구성요소 및 수량}

벼의 시비반응은 수량을 기준으로 평가하는 데, 벼 수량을 결정짓는 요인은 간장, 수장, 경 수, 수수, 등숙비율 등과 같은 수량구성요소에 의해서 결정된다. 우분액비 및 녹비작물도입에 의한 답리작 재배 후 벼 재배 시 수확기의 벼 수량구성요소와 수량의 연차별 및 평균치는 Table 3과 같다. 먼저 간장의 변화를 보면, 화 학비료 단작 표준구 $(\mathrm{MRS})$ 의 연차간 간장은 $90.6 \sim 95.3 \mathrm{~cm}$, 평균 $93.1 \mathrm{~cm}$ 로 처리 중 가장 길 었고 $(\mathrm{P}<0.05)$ 자운영 단작구 $(\mathrm{MRMV})$ 와 헤어리 베치 단작구 $(\mathrm{MRHV})$ 가 가장 짧았다 $(\mathrm{P}<0.05)$.
총체보리 2모작 우분액비 시용구 (DWBRC) 및 호밀 2모작 우분액비 시용구 (DWRRC)는 각각 $86.0 \sim 94.3 \mathrm{~cm}$ 및 $84.7 \sim 89.3 \mathrm{~cm}$, 평균 $89.7 \mathrm{~cm}$ 및 $87.5 \mathrm{~cm}$ 로 서로 비슷하였으며 녹비작물로 자운 영을 배치한 벼 단작구(MRMV) 및 헤어리베 치를 배치한 벼 단작구 $(\mathrm{MRHV})$ 에서는 각각 $80.5 \sim 86.1 \mathrm{~cm}$ 및 $81.5 \sim 88.0 \mathrm{~cm}$, 평균 $82.8 \mathrm{~cm}$ 및 $84.6 \mathrm{~cm}$ 로 다른 처리구에 비해 짧은 경향이었 다. 처리별 3 개년 평균 수장은 화학비료 단작 표준구가 가장 길었으며 $(\mathrm{P}<0.05)$ 다른 처리구 들은 비슷한 서로 비슷한 수준이었다. 처리별 3 개년 평균 수수 및 수당입수는 서로 비슷한 경향으로 화학비료 단작 표준구가 비교적 높고 다른 처리구는 서로 비슷한 수준이었다. 등숙 비율은 화학비료 단작 표준구, 총체보리 우분 액비 시용구 및 호밀 우분액비 시용구에서 88.7 89.9\%로 자운영 단작구 및 헤어리베치 단 작구의 85.6 86.4\%에 비해 높은 경향이었다 $(\mathrm{P}<$ 0.05).

처리별 백미의 평균수량은 화학비료 단작 표 준구가 $694 \mathrm{~kg} / 10 \mathrm{a}$ 으로 가장 높고 총체보리 우 분액비 시용구와 호밀 우분액비 시용구는 각각 619 및 $624 \mathrm{~kg} / 10 \mathrm{a}$ 으로 서로 비슷한 $(\mathrm{P}<0.05)$ 반 면에, 자운영 단작구와 헤어리베치 단작구는 499 및 $505 \mathrm{~kg} / 10 \mathrm{a}$ 으로 서로 비슷한 수준이었으 나 화학비료 단작 표준구와 총체보리 우분액비 시용구 및 호밀 우분액비 시용구에 비해 낮았 다. 이는 화학비료시용구에 비해 우분액비 시 용구는 우분액비를 전량기비로 시용한 결과 시 용초기에 질소 휘산량이 많고 무기화된 질소가 유기물의 분해에 쓰인 결과 화학비료보다 상대 적으로 질소공급량이 작아 초기생육이 부진한 결과로 생각된다 (김 등, 2004; Peter와 Amato, 2002; Jeon 등, 2003). 따라서 액비나 녹비작물 을 도입하여 벼를 재배할 때는 반드시 보충시 비가 있어야 벼 수량감소를 방지할 수 있으리 라 사료된다. 그러나 답리작 지역에서 우분액 비 시용과 녹비작물 도입에 따른 식용벼의 생 산에 관한 연구는 거의 이루어지지 않아 우분 
Table 3. Effect of cropping system and cattle slurry on total height, leaf height, number of stem, number of grain and dry matter (DM) yield of whole crop rice in paddy land

\begin{tabular}{|c|c|c|c|c|c|c|c|}
\hline Treatment & Year & $\begin{array}{l}\text { Culm } \\
\text { length } \\
\text { (cm) } \\
\end{array}$ & $\begin{array}{c}\text { Panicle } \\
\text { length } \\
(\mathrm{cm})\end{array}$ & $\begin{array}{c}\text { Panicle } \\
\text { number } \\
\text { (No.) } \\
\end{array}$ & $\begin{array}{c}\text { Spikelet } \\
\text { per panicle } \\
(\text { No. } / 20 \mathrm{~g}) \\
\end{array}$ & $\begin{array}{c}\text { Ripened } \\
\text { grain } \\
(\%) \\
\end{array}$ & $\begin{array}{c}\text { Grain } \\
\text { Yield } \\
(\mathrm{kg} / 10 \mathrm{a}) \\
\end{array}$ \\
\hline \multirow{4}{*}{$\mathrm{MRS}^{1)}$} & 2006 & $95.4 \pm 0.8$ & $20.0 \pm 0.4$ & $15.7 \pm 1.6$ & $833.7 \pm 27.1$ & $85.2 \pm 2.8$ & $558.0 \pm 71.7$ \\
\hline & 2007 & $93.4 \pm 0.5$ & $18.2 \pm 0.4$ & $15.7 \pm 1.4$ & $768.3 \pm 18.0$ & $89.9 \pm 1.3$ & $472.8 \pm 8.1$ \\
\hline & 2008 & $90.6 \pm 1.6$ & $18.9 \pm 0.7$ & $17.2 \pm 1.6$ & $768.7 \pm 95.9$ & $92.3 \pm 0.7$ & $614.2 \pm 30.4$ \\
\hline & Mean & $93.1 \pm 2.3 \mathrm{a}$ & $19.0 \pm 0.9 \mathrm{a}$ & $16.2 \pm 1.5$ & $790.2 \pm 60.2$ & $89.1 \pm 3.5$ & $548.3 \pm 73.0 \mathrm{a}$ \\
\hline \multirow{4}{*}{ DWBRC $^{2)}$} & 2006 & $86.1 \pm 0.6$ & $16.1 \pm 1.2$ & $14.1 \pm 1.7$ & $813.7 \pm 18.6$ & $90.4 \pm 2.7$ & $439.0 \pm 35.0$ \\
\hline & 2007 & $94.3 \pm 2.8$ & $17.4 \pm 0.4$ & $16.1 \pm 1.0$ & $790.3 \pm 18.1$ & $86.5 \pm 5.9$ & $465.8 \pm 67.4$ \\
\hline & 2008 & $88.6 \pm 1.6$ & $18.8 \pm 0.7$ & $16.4 \pm 2.4$ & $683.0 \pm 58.6$ & $89.3 \pm 2.2$ & $569.9 \pm 44.9$ \\
\hline & Mean & $89.6 \pm 4.0 \mathrm{~b}$ & $17.4 \pm 1.4 \mathrm{~b}$ & $15.6 \pm 1.9$ & $762.3 \pm 68.3$ & $88.7 \pm 3.8$ & $491.6 \pm 74.4 \mathrm{a}$ \\
\hline \multirow{4}{*}{ DWRRC $^{3)}$} & 2006 & $84.8 \pm 2.2$ & $15.3 \pm 0.9$ & $15.2 \pm 1.4$ & $814.0 \pm 30.3$ & $88.5 \pm 4.7$ & $441.0 \pm 34.3$ \\
\hline & 2007 & $89.3 \pm 2.7$ & $16.7 \pm 0.2$ & $15.3 \pm 1.5$ & $770.7 \pm 22.5$ & $90.5 \pm 1.3$ & $439.6 \pm 33.2$ \\
\hline & 2008 & $88.5+1.9$ & $19.0 \pm 0.9$ & $16.5 \pm 2.0$ & $698.7 \pm 81.3$ & $90.8 \pm 1.7$ & $593.2 \pm 1.5$ \\
\hline & Mean & $87.5 \pm 2.9 b c$ & $17.0 \pm 1.8 \mathrm{~b}$ & $15.7 \pm 1.5$ & $761.1 \pm 67.5$ & $90.0 \pm 2.8$ & $491.3 \pm 80.3 \mathrm{a}$ \\
\hline \multirow{4}{*}{$\mathrm{MRMV}^{4)}$} & 2006 & $80.5 \pm 4.6$ & $15.4 \pm 4.3$ & $14.8 \pm 0.8$ & $839.3 \pm 9.7$ & $87.5 \pm 2.0$ & $348.0 \pm 14.1$ \\
\hline & 2007 & $81.7 \pm 5.5$ & $15.2 \pm 0.9$ & $15.0 \pm 0.7$ & $802.7 \pm 26.1$ & $80.6 \pm 5.7$ & $387.7 \pm 88.8$ \\
\hline & 2008 & $86.1 \pm 1.4$ & $18.6 \pm 1.0$ & $16.8 \pm 1.7$ & $611.0 \pm 88.2$ & $88.7 \pm 1.4$ & $435.1 \pm 37.5$ \\
\hline & Mean & $82.8 \pm 4.5 \mathrm{~d}$ & $16.4 \pm 2.8 \mathrm{~b}$ & $15.5 \pm 1.4$ & $751.0 \pm 115.8$ & $85.6 \pm 4.9$ & $390.3 \pm 61.6 \mathrm{~b}$ \\
\hline \multirow{4}{*}{$\mathrm{MRHV}^{5)}$} & 2006 & $81.6 \pm 1.4$ & $16.8 \pm 0.4$ & $12.8 \pm 0.3$ & $837.0 \pm 28.9$ & $90.4 \pm 1.8$ & $329.1 \pm 11.8$ \\
\hline & 2007 & $84.4 \pm 4.3$ & $16.2 \pm 1.5$ & $15.1 \pm 1.0$ & $798.7 \pm 6.7$ & $81.2 \pm 7.8$ & $403.6 \pm 53.1$ \\
\hline & 2008 & $88.0 \pm 1.5$ & $17.0 \pm 0.6$ & $16.9 \pm 1.0$ & $619.0 \pm 86.7$ & $87.8 \pm 5.0$ & $448.9 \pm 14.4$ \\
\hline & Mean & $84.7 \pm 3.6 \mathrm{~cd}$ & $16.7 \pm 0.9 b$ & $14.9 \pm 1.9$ & $751.6 \pm 110.7$ & $86.5 \pm 6.3$ & $393.9 \pm 59.5 b$ \\
\hline
\end{tabular}

\footnotetext{
${ }^{1)}$ mono-cropping rice applied with standard fertilizer (MRS),

2) double-cropping whole crop barley following rice applied with cattle slurry (DWBRC),

3) double-cropping whole crop rye following rice applied with cattle slurry (DWRRC),

${ }^{4)}$ mono-cropping rice applied with following milk vetch (MRMV), and

${ }^{5)}$ mono-cropping rice applied with following hairy vetch (MRHV).

a and b: Means with different letters within a column are significantly different at the 5\% level.
}

액비와 녹비작물의 이용성에 관한 판단을 내리 기에는 부족한 점이 많기 때문에 더 많은 연구 가 진행되어야 할 것으로 생각된다.

\section{2모작 사료작물의 사료가치 및 생산성}

벼 재배 후 우분액비를 시용하여 2모작으로 재배한 사료작물의 3 개년 평균 사료가치 및 생 산성은 Table 4와 같다. 총체보리 및 호밀의 조 단백질 $(\mathrm{CP})$ 함량이 각각 7.47 및 $7.54 \%$ 를 나타
낸 반면에, 자운영과 베치는 19.01 및 $21.84 \%$ 를 나타냈다. 2모작 답리작물인 총체보리와 호 밀의 $\mathrm{TDN}$ 함량은 각각 60.5 및 $60.2 \%$ 로 서로 비슷하였지만, 총체보리의 건물수량이 호밀의 거의 두 배 $(\mathrm{P}<0.05)$ 에 달해 답리작으로 호밀보 다 총체보리를 재배하는 것이 훨씬 유리한 것 으로 나타났다. 한편 녹비작물인 자운영과 베 치의 성분함량 및 수량을 보면, 조단백질 함량 은 자운영 및 베치에서 각각 19.01 및 $21.84 \%$ 를 나타낸 반면에 $\mathrm{NDF}, \mathrm{ADF}$ 및 $\mathrm{TDN}$ 함량은 
Table 4. Effect of cropping system and cattle slurry as fertilizer materials on dry matter (DM) yield and nutritive value of forage in paddy land

\begin{tabular}{|c|c|c|c|c|c|c|}
\hline \multirow{2}{*}{ Forage } & \multirow{2}{*}{ Year } & $\mathrm{CP}$ & $\mathrm{NDF}$ & $\mathrm{ADF}$ & TDN & \multirow{2}{*}{$\begin{array}{c}\text { DM yield } \\
(\mathrm{kg} / 10 \mathrm{a}) \\
\end{array}$} \\
\hline & & \multicolumn{4}{|c|}{$(\% / \mathrm{DM})$} & \\
\hline \multirow{3}{*}{$\begin{array}{c}\text { whole crop } \\
\text { barley in } \\
\text { DWBRC }^{1)}\end{array}$} & 2007 & $7.21 \pm 0.86$ & $66.64 \pm 2.88$ & $33.54 \pm 2.00$ & $62.40 \pm 1.58$ & $814.0 \pm 19.5$ \\
\hline & 2008 & $7.07 \pm 0.44$ & $64.30 \pm 2.66$ & $38.32 \pm 2.67$ & $58.63 \pm 2.11$ & $755.0 \pm 111.7$ \\
\hline & Mean & $7.47 \pm 0.75 \mathrm{c}$ & $65.47 \pm 2.79 a$ & $35.93 \pm 3.36$ & $60.52 \pm 2.65$ & $784.8 \pm 78.8 \mathrm{a}$ \\
\hline \multirow{3}{*}{$\begin{array}{c}\text { whole crop } \\
\text { rye in } \\
\text { DWRRC }^{2)}\end{array}$} & 2007 & $7.97 \pm 0.71$ & $60.94 \pm 1.23$ & $35.27 \pm 1.35$ & $61.03 \pm 1.06$ & $507.0 \pm 41.8$ \\
\hline & 2008 & $7.18 \pm 0.87$ & $62.15 \pm 4.07$ & $37.48 \pm 1.15$ & $59.29 \pm 0.91$ & $340.0 \pm 28.0$ \\
\hline & Mean & $7.54 \pm 0.86 \mathrm{c}$ & $61.55 \pm 2.77 \mathrm{~b}$ & $36.38 \pm 1.65$ & $60.16 \pm 1.30$ & $438.6 \pm 81.6 b$ \\
\hline \multirow{3}{*}{$\begin{array}{l}\text { milk vetch in } \\
\text { MRMV }^{3)}\end{array}$} & 2007 & $18.72 \pm 0.72$ & $57.19 \pm 1.42$ & $33.51 \pm 1.43$ & $61.89 \pm 0.26$ & $52.7 \pm 1.01$ \\
\hline & 2008 & $19.29 \pm 2.68$ & $58.72 \pm 3.38$ & $34.53 \pm 1.03$ & $61.62 \pm 0.81$ & $55.0 \pm 2.0$ \\
\hline & Mean & $19.01 \pm 1.78 b$ & $57.95 \pm 2.46 \mathrm{c}$ & $34.02 \pm 1.25$ & $61.76 \pm 0.56$ & $53.85 \pm 1.9 \mathrm{~d}$ \\
\hline \multirow{3}{*}{$\begin{array}{c}\text { hairy vetch in- } \\
\text { MRHV }^{4}\end{array}$} & 2007 & $22.57 \pm 1.14$ & $61.53 \pm 2.65$ & $34.36 \pm 1.46$ & $60.43 \pm 1.31$ & $396.90 \pm 10.5$ \\
\hline & 2008 & $21.11 \pm 1.99$ & $61.33 \pm 4.00$ & $35.86 \pm 2.81$ & $60.57 \pm 2.84$ & $305.0 \pm 15.8$ \\
\hline & Mean & $21.84 \pm 1.65 \mathrm{a}$ & $61.43 \pm 3.04 \mathrm{~b}$ & $35.11 \pm 2.17$ & $60.50 \pm 1.98$ & $350.9 \pm 51.7 \mathrm{c}$ \\
\hline
\end{tabular}

\footnotetext{
${ }^{1)}$ double-cropping whole crop barley following rice applied with cattle slurry (DWBRC),

${ }^{2)}$ double-cropping whole crop rye following rice applied with cattle slurry (DWRRC),

${ }^{3)}$ mono-cropping rice applied with following milk vetch (MRMV), and

${ }^{4)}$ mono-cropping rice applied with following hairy vetch (MRHV).
}

$\mathrm{a}, \mathrm{b}$ and $\mathrm{c}$ : Means with different letters within a column are significantly different at the $5 \%$ level.

비슷하였다. 그러나 자운영의 건물 수량은 $10 \mathrm{a}$ 당 $53.5 \mathrm{~kg}$ 으로 베치의 $15 \%$ 정도에 불과하였다 $(\mathrm{P}<0.05)$. 자운영 및 베치의 파종은 벼 수확직 전 입모중에 손으로 산파한 것으로 수확 시 기 계작업으로 포장이 평탄하지 못한 관계로 녹비 작물의 발아에 나쁜 영향을 준 것으로 생각되 는데, 특히 자운영의 경우는 본 시험지역의 녹 비작물로써 기후 등 환경적으로 재배가 적절치 않은 것으로 보인다. 지금까지 우분액비를 이 용한 답리작 2모작 작부체계에서의 벼와 사료 작물의 생산, 그리고 녹비작물의 이용성을 높 일 수 있는 연구는 거의 이루어지지 않고 있는 실정이므로 답작에서 가축분뇨액비와 녹비작물 을 연계한 작부체계에 관한 많은 연구가 이루 어져야 할 것으로 생각된다.

\section{3. 토양 화학성분의 변화}

우분액비 및 녹비작물 도입에 의한 3 년간 벼
재배 후 시험 종료시 처리형태별 토양성분은 Table 5에서 보는 바와 같다. 토양의 $\mathrm{pH}$ 는 화 학비료 단작 표준구 (MRS)를 제외한 모든 처리 구에서 시험초기에 비해 높아지는 경향을 보였 다. 토양내 유기물 함량은 시험 종료시 총체보 리 우분액비 시용구(DWBRC), 호밀 우분액비 시용구 (DWRRC), 자운영 단작구 (MRMV) 및 베치 단작구 $(\mathrm{MRHV})$ 에서 각각 $43.52,47.37$, 42.39 및 $37.51 \mathrm{~g} / \mathrm{kg}$ 으로 화학비료구의 30.14 $\mathrm{g} / \mathrm{kg}$ 보다 높게 나타났으며 $(\mathrm{P}<0.05)$ 모든 처리 에 있어 시험초기에 비해 높아지는 경향 $(\mathrm{P}<$ 0.05)을 보였는데, 이는 우분액비의 높은 유기 물 함량 때문에 토양내 유기물 함량이 증가한 것으로 보인다. 토양내 총 질소 $(\mathrm{T}-\mathrm{N})$ 함량은 처리간에 $1.07 \sim 1.42 \mathrm{~g} / \mathrm{kg}$ 으로 서로 비슷한 수준 이었으며 시험초기의 $1.44 \sim 1.82 \mathrm{~g} / \mathrm{kg}$ 에 비해 약 간 낮아졌다. 토양내 유효인산 $\left(\mathrm{Av} . \mathrm{P}_{2} \mathrm{O}_{5}\right)$ 함량 도 유기물 및 총 질소 함량과 비슷하게 화학비 료 단작 표준구의 $71.67 \mathrm{ppm}$ 에 비해 75.27 
Table 5. Effect of cropping system and cattle slurry as fertilizer materials on the characteristics of soil collected at the end of experiment in paddy land

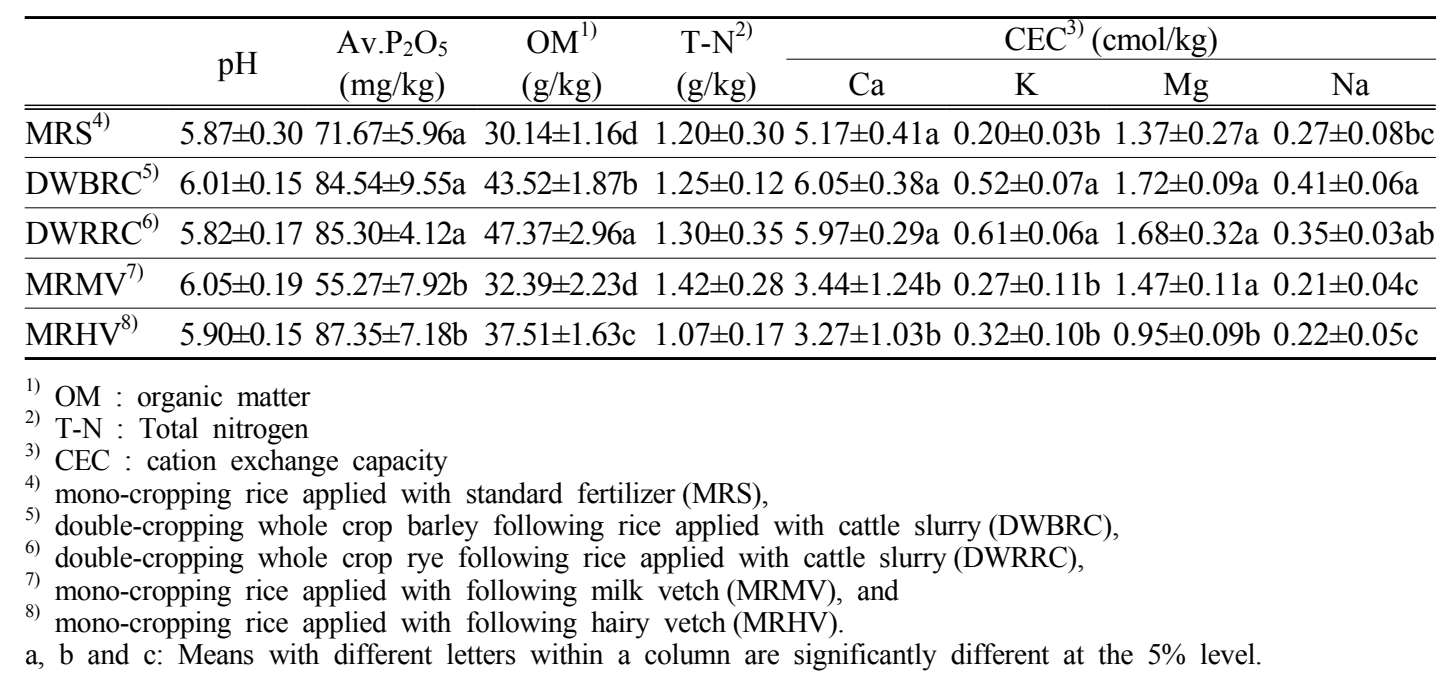

$87.35 \mathrm{ppm}$ 으로 보다 높은 경향을 보였으며 모 든 처리에 있어 시험초기에 비해 높아지는 경 향을 보였다. 일반적으로 가축분을 시용하면 토양중 인산함량이 증대되는데 본 시험 결과 인산함량이 높지 않은 이유는 액비중 인산 함 량이 낮았으며, 벼를 재배하였기 때문으로 생 각된다. 양이온 치환용량도 우분액비 시용이나 녹비작물 도입구가 화학비료 단작 표준구에 비 해 높게 나타났으며 우분액비 시용이 녹비작물 도입구에 비해 더 높은 경향을 보였다. 우분액 비 및 녹비작물 도입에 의한 벼 재배는 토양내 $\mathrm{pH}$, 유기물, 유효인산 함량 및 양이온 치환용 량이 화학비료 단작 표준구에 비해 높게 나타 났을 뿐만 아니라 시험초기의 토양성분에 비해 서도 증가하였는데, 이는 돈분액비에 의한 시 험결과(김 등, 2004, Hountin 등, 2000; Choudhary 등, 1996; Kim 등, 2001)와 유사하다. 따라서 우분액비 및 녹비작물 도입에 의한 벼 재배는 토양개선 효과가 있으며 화학비료를 충분히 대 체할 수 있을 것으로 사료되지만, 가축분뇨 연 용은 토양의 물리성이 나빠진다는 보고(Ushio 등, 2000; Anzai, 1987)도 있어 연용 연차별 토 양특성변화를 검토할 필요가 있다고 생각된다.

이상의 결과에서 보는 바와 같이 답작에서
우분액비 시용과 녹비작물 도입은 토양의 성분 변화에 영향을 주는 것으로 나타났다. 그러나 우분액비와 녹비작물의 이용, 그리고 2 모작 작 부체계에서의 토양의 이화학적 특성에 영향을 미치는 주요인 등에 대한 더 많은 연구가 진행 되어야만 토양과 환경을 보존하면서 사료작물 과 벼 생산이 가능할 것으로 보인다. 따라서 답작에서 우분액비와 녹비작물을 이용한 2모작 작부체계에 대한 많은 연구가 수행되어야 할 것으로 생각된다.

\section{4. 논물 화학성분의 변화}

벼 재배기간 동안 논물 배출수의 $\mathrm{pH}, \mathrm{NO}_{3}-\mathrm{N}$, $\mathrm{NH}_{4}-\mathrm{N}$ 및 $\mathrm{PO}_{4}$ 의 변화를 나타낸 것은 Fig. 1, 2 및 3 과 같다. 먼저 $\mathrm{pH}$ 는 2007년도의 화학비료 단작 표준구 (MRS)에서 7.44 7.91, 총체보리 우 분액비 시용구 (DWBRC)는 7.45 7.97, 호밀 우 분액비 시용구 (DWRRC)는 7.48 8.06, 자운영 단작구 $(\mathrm{MRMV})$ 및 베치 단작구 $(\mathrm{MRHV})$ 는 각 각 7.29 7.92 및 7.33 7.96의 범위내에서 변동 하였으며, 다음해 (2008년)도 전년도 (2007년)와 거의 비슷한 양상으로 비슷한 범위내에서 변동 하였다. $\mathrm{NO}_{3}-\mathrm{N}$ 농도는 2007년도에 화학비료 

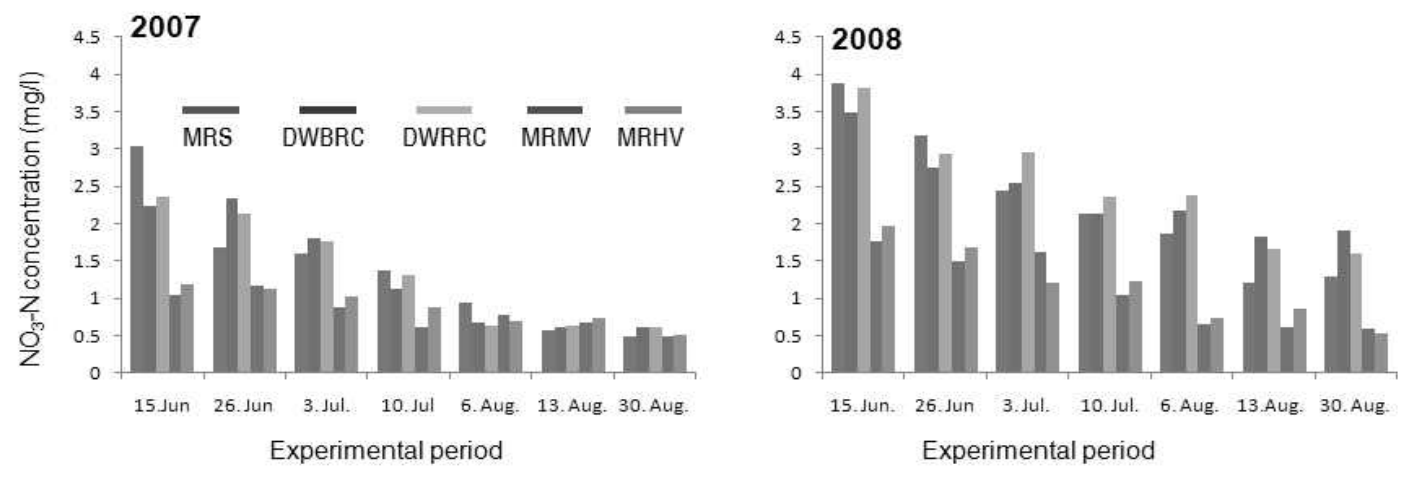

Fig. 1. The level of $\mathrm{NO}_{3}-\mathrm{N}$ in discharge water from paddy land by cropping system and cattle slurry as fertilizer materials during the experimental period.
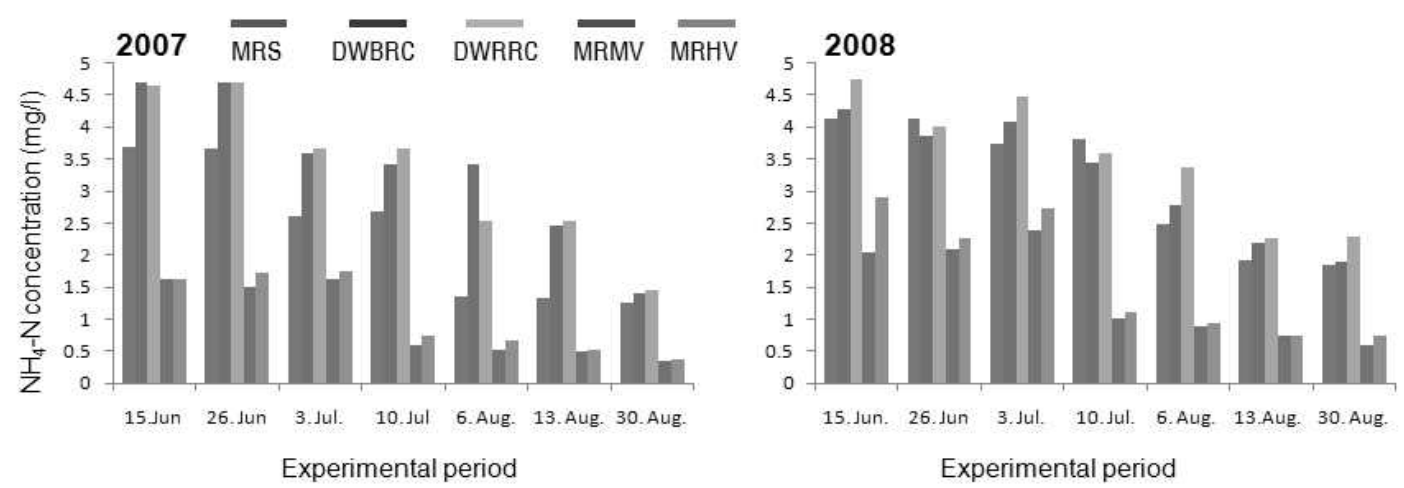

Fig. 2. The level of $\mathrm{NH}_{4}-\mathrm{N}$ in discharge water from paddy land by cropping system and cattle slurry as fertilizer materials during the experimental period.

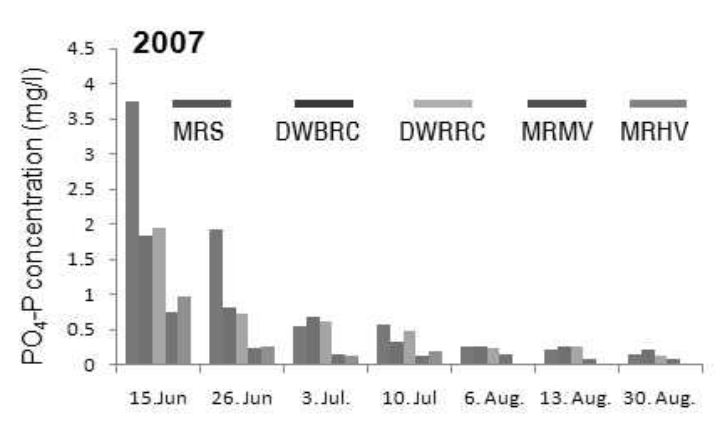

Experimental period

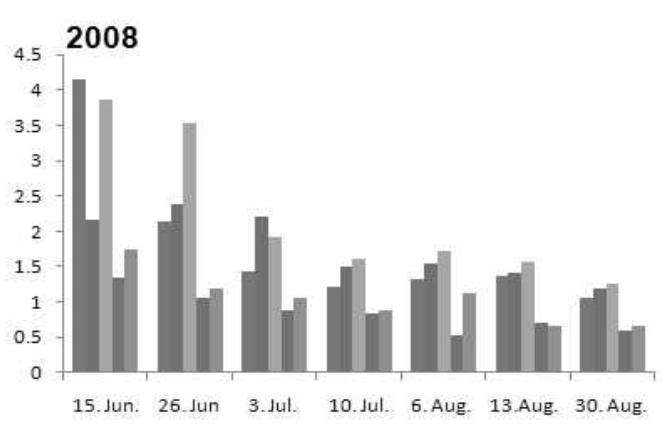

Experimental period

Fig. 3. The level of $\mathrm{PO}_{4}-\mathrm{P}$ in discharge water from paddy land by cropping system and cattle slurry as fertilizer materials during the experimental period.

단작 표준구는 3.04 1.48 ppm, 총체보리 우분액

비 시용구는 2.24 1.62 ppm, 호밀 우분액비 시 용구는 2.35 1.60 ppm, 자운영 단작구 및 베치 단작구는 각각 $1.05 \sim 0.49 \mathrm{ppm}$ 및 $1.19 \sim 0.51 \mathrm{ppm}$
의 범위내에서 변동하였으며, 연차별로 거의 비슷한 양상으로 이양 후 시일이 경과할수록 낮아지는 경향을 보였다. $\mathrm{NH}_{4}-\mathrm{N}$ 농도도 $\mathrm{NO}_{3}-\mathrm{N}$ 농도변화와 비슷한 양상으로 2007년에는 화학 
비료 단작 표준구에서 $3.68 \sim 1.25 \mathrm{ppm}$, 총체보리 우분액비 시용구는 4.69 2.41 ppm, 호밀 우분액 비 시용구는 $4.64 \sim 2.45 \mathrm{ppm}$, 자운영 단작구 및 베치 단작구는 각각 $1.63 \sim 0.36 \mathrm{ppm}$ 및 1.62 $0.58 \mathrm{ppm}$ 의 범위내에서 변동하였다. 한편 2차년 도 (2008년)의 배출수 중 $\mathrm{NH}_{4}-\mathrm{N}$ 농도는 화학비 료 단작 표준구에서 4.14 1.85, 총체보리 우분 액비 시용구는 4.29 1.90, 호밀 우분액비 시용 구는 4.75 2.29, 자운영 단작구 및 베치 단작구 는 각각 2.04 0.59, 2.91 0.73의 범위내에서 변 동하여 1 차년도와 거의 비슷한 양상으로 이양 후 시일이 경과할수록 낮아지는 경향을 보였 다. 한편 배출수 중 1 차년도 $\mathrm{PO}_{4}$ 의 농도는 화 학비료 단작 표준구에서 $3.74 \sim 0.25$, 총체보리 우분액비 시용구는 $1.84 \sim 0.26$, 호밀 우분액비 시용구는 $1.95 \sim 0.22$, 자운영 단작구 및 베치 단 작구는 각각 $0.55 \sim 0.1,0.67 \sim 0.13$ 의 범위내에서 변동하였으며 2 차년도도 1 차년도와 거의 비슷 한 양상으로 이양 후 시일이 경과할수록 낮아 지는 경향을 보였는데, 이는 벼 생육에 의한 양분 흡수 및 배출수량의 증가에 의해 낮아진 것으로 보인다. 한편 처리별로 보면, 화학비료 단작 표준구에 비하여 총체보리 우분액비 시용 구 및 호밀 우분액비 시용구에서 $\mathrm{NO}_{3}-\mathrm{N}$, $\mathrm{NH}_{4}-\mathrm{N}$ 및 $\mathrm{PO}_{4}$ 농도가 약간 높게 나타났다.

\section{IV. 요 약}

본 연구는 우분액비 및 녹비작물 도입에 의 한 답리작 사료작물을 재배하여 수확한 다음 우분액비시용이 벼 및 후작물인 답리작 사료작 물의 생산성, 토양의 지력증진 효과 및 양분이 동에 미치는 영향을 조사하기 위하여 전라북도 축산진흥연구소내 식양토의 논에서 2006년 4월 부터 2009년 4월까지 3개년에 걸쳐 수행하였 다. 우분액비 시용은 벼는 이앙 전에 전량 기 비로 시용하였으며 총체보리 및 호밀은 파종전 과 봄 생육 개시 전에 2회 균등분할 시용하였 는데, 화학비료 대비 우분액비의 시용수준은 $\mathrm{N}$
를 기준으로 하였다. 처리는 벼 화학비료 단작 표준구, 벼 +총체보리 2모작 우분액비 시용구, 벼+호밀 2모작 우분액비 시용구, 벼+자운영 및 벼+베치로 구성하여 5 처리 완전임의배치 3 반복 으로 배치하였으며 벼는 농가관행에 준하여 재 배되었다. 3 개년 평균 벼 수량구성요소 및 수 량에 있어서 초장 및 수장은 화학비료 단작 표 준구가 가장 길었으며 경수 및 낱알 수도 화학 비료 단작 표준구가 가장 많았다. 등숙율은 화 학비료 단작 표준구, 총체보리 우분액비 시용 구 및 호밀 우분액비 시용구가 비슷한 수준으 로 자운영 단작구 및 베치 단작구에 비해 높았 다. 현미수량은 화학비료 단작 표준구가 가장 많았고 자운영 단작구 및 베치 단작구는 비슷 한 수준으로 총체보리 우분액비 시용구 및 호 밀 우분액비 시용구에 비해 낮았다. 벼와 2모 작으로 재배한 총체보리의 수량이 호밀에 비해 더 높게 나타났다. 경작형태별 우분액비시용에 따른 토양내 $\mathrm{pH}, \mathrm{P}_{2} \mathrm{O}_{5}, \mathrm{~T}-\mathrm{N}, \mathrm{OM}$ 농도 및 치환 성 양이온의 농도는 시험전에 비해 시험종료후 에 현저하게 증가하는 경향을 나타냈다. 배출 수 중 $\mathrm{NO}_{3}-\mathrm{N}, \mathrm{NH}_{4}-\mathrm{N}$ 및 $\mathrm{PO}_{4}$ 농도는 총체보리 및 호밀 우분액비 시용구가 화학비료 단작 표 준구에 비하여 약간 높게 나타났으며 이앙 후 시일이 경과할수록 낮아졌다.

\section{VI. 인 용 문 헌}

1. 김종구, 이경보, 이덕배, 이상복, 나승용. 2004. 배수조건이 다른 논에서 돈분뇨 액비시용이 벼 생육 및 양분이동에 미치는 영향. 한국토양비료 학회지 37(2):97-103.

2. 농림부, 농촌진흥청 축산기술연구소. 2000. 가축 분뇨자원화 및 이용기술 개발 (제 2권)

3. 농촌진흥청. 1989. 토양화학분석법

4. 육완방. 1990. 영년혼파초지에 있어서 예취빈도 와 질소시비수준이 $\mathrm{NO}_{3}-\mathrm{N}$ 의 유실에 미치는 영 향. 한초지. 10(2):84-88.

5. 임영철, 윤세형, 정민웅, 김원호, 김종근, 이종경, 서 성, 박남건, 육완방. 2007. 가축분뇨시용이 총체벼의 생산성, 사료가치 및 토양의 화학성에 
미치는 영향. 한초지 27(4):287-296.

6. 임영철, 윤세형, 김원호, 김종근, 신재순, 정민웅, 서 성, 육완방. 2006. 논에서 수수 $\times$ 수단그라스 교잡종 재배시 가축분뇨 이용이 생육특성, 수량, 사료가치 및 $\mathrm{NO}_{3}-\mathrm{N}$ 의 용탈에 미치는 영향. 한초 지 26(4):233-238.

7. Anzai, T. and N. Matsumoto. 1987. Effects of annual application of swine urine on the physicochemical properties and the heavy metal contents of paddy soil. Soil. Plant Nutr. 58:433-439.

8. Choudhary, M., L.D. Bailey, and C.A. Grant. 1996. Review of the use of swine manure in crop production: Effect on yield and composition on soil and water quality. Waste. Manage. Res. 14: 581-595.

9. Davies, D.B., T.W.D. Garwood and A.D.H. Rochford. 1996. Factors affecting nitrate leaching from a calcareous loam in East Anglia. Journal of Agricultural Science, Cambrige 126:75-86.

10. Gilley, J.E., B. Eghball, J.M. Blumenthal and D.D. Baltensperger. 1999. Run-off and erosion from inter rill areas as affected by the application of manure. Transactions of the ASEA 42(4): 975-980.

11. Goering, H.K. and P.J. Van Soest. 1970. Forage fiber analysis. Agric. Handbook 379, U.S. Gov. print. Office, Washington, DC.

12. Goh V.M. and Vityakon P. 1986. Effects of fertilizers on vegetable production 2. Effects of nitrogen fertilizers on nitrogen content and nitrate accumulation of spinach and beetroot. N.Z.J. Agr. Rs. 29:485-494.

13. Hountin, J.A. and A. Karam, and D. Couillard. 2000. Use of a fractionation procedure to access the potential for $\mathrm{P}$ movement in a soil profile after 14 years of liquid pig manure fertilization. Agr. Ecosyst. Environ. 78:77-84.

14. Jarvis, S.C., M. Sherwood and J.H.A.M. Steenvoorden. 1987. Nitrogen losses from animal manure from grazed pastures and from applied slurry. In: Van Der Meer,

15. Jeon, W.T, H.M. Park, C.Y. Park, K.D. Park, Y.S. Cho, E.S. Yun, and U.G. Kang. 2003. Effect of liquid pig manure application on rice growth and environment of paddy soil. Korean J. Soil. Sci. Fert. 36:333-343.
16. Jurgen, M.H. 1982. Animal feeding and and nutrition. Kentall \& Hunt Publishing, Inc. Virginia.

17. Kim, M.C., D.J. Choi and S.T. Song. 2001. Effect of swine liquid manure and phosphorous fertilizer application level on dry matter yield and $\mathrm{N}$ and $\mathrm{P}$ uptake of Italian ryegrass. J. Anim. Sci. Technol. 43:973-980.

18. Legg, J.O. and J.J. Meisinger. 1982. Soil nutrition budgets in nitrogen in agricultural soils. In: FJ. Stevenson ed.) Nitrogen in agricultural soils. Agron. Monogr. 22. ASA, CSSA, Madison, WI.

19. McCalla, T.M. 1974. Use of animal manure wastes as a soil amendment. J. Soil Water Conserv. 29:213-216.

20. Murayama, S., N. Kibo, M. Komada, K. Baba, and A. Tsumura. 2001. Water quality, particularly of trihalomethane formation potential of ground water of agricultural area of humic volcanic ash soil on Shirash Plateau where livestock wastes have been applied as land management. Soil Sci. Fret. 34:147-152.

21. Peter, S. and M. Amato. 2002. Remineralization and residual effects of $\mathrm{N}$ after application of pig slurry to soil. Eur. J. Agron. 16:81-95.

22. Pye, V.I. 1983. Groundwater contamination in the United States. Workshop on groundwater Resources and Contamination in the United States (Summary and Papers). Natl. Sci. Foundation. Washington DC.

23. RDA. 1995. Standard methods for agricultural experiment. Rural Development Administration, Suwon, Korea.

24. Ushio, S., N. Yosimura, K. Saito, and N. Nagajima. 2000. Nitrogen decomposition rate of animal wastes composts and dry wastes for 141 days in summer and estimation. Soil Sci. Plant Nutr. 71:249-253.

25. Yadav, R.L., B.S. Dwivedi, K. Prasad and P.S. Pandy. 2000. Yield trends, and changes in soil organic-C and available NPK in a long-term ricewheat system under integrated use of manure and fertilizers. Field Crop. Res. 68:219-246.

(접수일: 2011년 1월 5일, 수정일 1차: 2011년 1월 10일, 수정일 2차: 2011년 2월 26일, 게재확정일: 2011년 2월 15일) 